\author{
Ljiljana Lovrić \\ University of Rijeka, Faculty of Economics, Rijeka, Croatia \\ Vinko Kandžija \\ University of Rijeka, Faculty of Economics, Rijeka, Croatia \\ Jelena Babić \\ University of Rijeka, Faculty of Economics, Rijeka, Croatia
}

\title{
ATTRACTIVENESS OF CENTRAL EUROPEAN TRANSITIONAL COUNTRIES FOR FOREIGN INVESTMENT*
}

Key words: transition, analytic hierarchy process, investments

\section{$\underline{\text { ABSTRACT }}$}

In this article Central European Countries are ranked depending on how attractive they are to international companies for investment. In the process of managerial decision-making about investment, companies mostly use statistical data published by international institutions. Such wide and heterogeneous set of quantitative and qualitative information need to be compared and analyzed systematically, and it can be done by using the method of Analytical Hierarchy Process (AHP). An estimation is performed considering two important aspects simultaneously - the level of institutional reforms being realized and the level of economic performances attained by an individual country.

\section{INTRODUCTION}

Intensive globalization processes have been recognized as the major trend of the world economy in the course of the last two decades, manifested as enhancing the links among national economies, creating the world market in goods and services, and particularly in capital. The trend of global capital i.e. foreign direct investments as its main and most important component have shown progressive increase from USD 57.6 billion in 1985 up to nearly USD 1.4 trillion in the record year 2000 which was almost 25 -fold increase in only 15 years, with the most intensive growth realized in the last 90 ties of the previous century.

Considering global trends one should be aware of the fact that this is a heterogeneous group of countries of which only some have succeeded in taking advantage in

\footnotetext{
* This article is the result of the scientific projects "Quantitative Analysis of Croatian Economy Productivity and EU Integration" $n^{\circ}$ 081-0811403-1410 and "Development of Croatian Economic Competitiveness in the Process of EU Accession" nº 081-0811403-1405, both financed by Croatian Ministry of Science, Education and Sports.
} 
globalization and have drawn considerable foreign investments contributing to their rapid economic growth. Within European countries similar trends appeared in the early 90ties of the previous century when the Mid and East European countries started the transitional process from the planned to market economy. At the beginning of that period (1990) foreign investments into transitional countries amounted to mere USD 1 billion which was under 1\% of FDI into developed countries. In the next years direct investments into transitional countries grew rapidly and in the year 2000 reached almost USD 25 billion. But it is still incomparable to the level of FDI in developed European countries which in 2000 reached USD 720 billion $^{1}$. After the period of the world economy stagnation and global drop of investment level, the trends of growth have continued in which the increase in transitional countries has been more significant. Of course, the fact that in some countries the processes of liberalization and reform started later and differed in dynamics resulted in different time of realizing the predispositions for foreign investments. Accordingly, ten new members that join the EU in 2004 realized already in the previous decade a better growth of foreign investments, while other transitional countries awaiting the EU membership have been catching up recently. Still, the investment level that some transitional countries have attained varies considerably. So the leaders are Hungary, the Czech Republic and Poland, that constantly attract yearly more than $50 \%$ of transitional countries FDI.

Companies operating in international environment need to evaluate the potential transitional countries attractiveness with which they may want to do business. They must consider not only specific factors such as the supply of raw materials, infrastructure requirements etc. Nowadays they must consider the macro environment which means economic, financial and political factors, as well the reached level of transition process. These are direct and indirect conditions which could represent threats or opportunities to business. In the process of managerial decision-making about investment, companies mostly use statistical data published by international institutions.

Such wide and heterogeneous set of quantitative and qualitative information need to be compared and analyzed systematically. Classical quantitative methods and modeling are not suitable for such complex hierarchical structured decision-making task. In this paper it is done by using an utility function and the method of Analytical Hierarchy Process (AHP).

This is a continuation of the earlier research (Lovrić,Lj.(2004)). The attempt of the paper is to develop an AHP model which will include two important aspects simultaneously - the level of institutional reforms being realized and the level of economic performances attained by an individual country. Political factors, stability and human rights are also very important, but we may consider the CEE countries as a homogenous group from this point of view and we neglected these influences.

There are numerous fields of AHP applications but this research of countries investment attractiveness is specific in a way of including institutional reform

\footnotetext{
${ }^{1}$ http://stats.unctad.org/fdi/
} 
measuring as one of the aspects, especially because of measuring the various complexity of each reform area.

\section{AHP PROCEDURE}

Decision making may be very complicated when we have more criterions and alternatives. In mathematics is known the method of establishing the influence of one variable on a function if the other variables are considered constant. The method of AHP is in fact extended in the way of establishing the influence of every "variable" towards another, observed in pairs. Even of grater significance is that both qualitative and quantitative factors and criteria are equally introduced in this comparison. The AHP provides a mathematical process to input subjective and personal preferences of decision maker, allowing inconsistency in judgments, and provides a means to improve consistency.

According to Thomas A. Saaty (1986), there are three principles when conducting problem solving and they are built in the methodology of AHP: Principle of decomposition, principle of comparative judgements and principle of synthesis of priorities.

The first principle is included in the first step of procedure: Breaking down a complex situation into its component parts arranging it into a hierarchic order of goal, criteria, subcriteria, alternatives. In the second step, as a result of comparative judgements the pairwise comparison matrix is constructed. Each criterion is compared to every other criterion on the basis of 1 to 9 ratio scale of intensities. Comparing criterion i to j, aij represents the importance of criterion $i$ over criterion $j$. Since each criterion is of equal importance to itself aii $=1$. Comparing criterion $\mathrm{j}$ to $\mathrm{i}$, aji is simply reciprocal of aij. Each pair judgment is one cell value in square matrix. That is pairwise comparison matrix of criterion. We have to make pairwise comparing of alternatives inside each criterion too and generate the pairwise comparison matrices. The third step comprises the vector of priorities calculation. There are possibilities of errors in subjective judgments. But there is also a way to measure these judgments for errors by consistency testing with consistency index (CI) and consistency ratio (CR). As the CI approaches to zero the judgments are more consistent. It can be compared to RI (the average CI of randomly generated matrices of the same order) and it is named a consistency ratio (CR) If this $\mathrm{CR}$ fails to reach the required level then judgments of comparisons should be re-examined.

\section{MODEL SPECIFICATION}

The hierarchical structure of AHP model comprises goal, criteria, subcriteria and alternatives. The goal is the aim of our research, that is foreign investment attractiveness of European transitional countries. Then there are two criteria: the reached level of institutional reforms and the attained economic performances. Each criteria has subcriteria, and these are main factors through which it is possible to measure or analyze criteria. 
Transitional factors which will be considered are institutional reforms:

- Large-scale privatization;

- Small-scale privatization;

- Governance and enterprise restructuring;

- Price liberalization;

- Trade and foreign exchange system;

- Competition policy;

- Banking reform and interest rate liberalization;

- Security markets and non-bank financial institutions.

Economic - financial factors we consider are ${ }^{2}$ :

- GDP growth rate, to give evidence about the economic forces of the country;

- GDP p/c, to monitor the present richness of the country;

- Inflation rate is an indicator of stability in managing exchange rate and of potential

- future development;

- Current account over GDP, is an indicator of a country's proneness to invest;

- Risk of direct investment, is a way to monitor the credit worthiness of a country.

Each subcriteria has alternatives, in this case there are grades with which we measure the levels of subcriteria. According to AHP methodology, the model of our problem is presented in Figure 1.

\subsection{The left side of AHP model}

The left side of the model comprises iinstitutional reforms which are the core of transition process from a centrally planned economy to a market economy. These multidimensional changing process is more difficult to quantify and compare than macroeconomic indicators. It comprises eight categories of transition reforms, incomparable with each other because of various reforms complexity. Each of area or category has different duration, intensity and complexity over time. Progress in the areas, measured by EBRD transition indicator is a good, simple, quantitative indicator when it is used to show the score of reforms that are carried out in transitional countries, but only inside one area or category of reform. So to make comparisons between categories or areas we have to give them various weights to be able to compare them. We shall use AHP to determine the weights, which will be the measure of realisation complexity of each category.

As it is exposed, the AHP method comprises judgement consistency or to put it simply the way to test and avoid entirely subjective judgements or judgement errors.

\footnotetext{
${ }^{2}$ Saaty \& Vargas 2001, for the group of developing countries from 6 geographical regions.
} 
Figure 1 Hierarchical structure

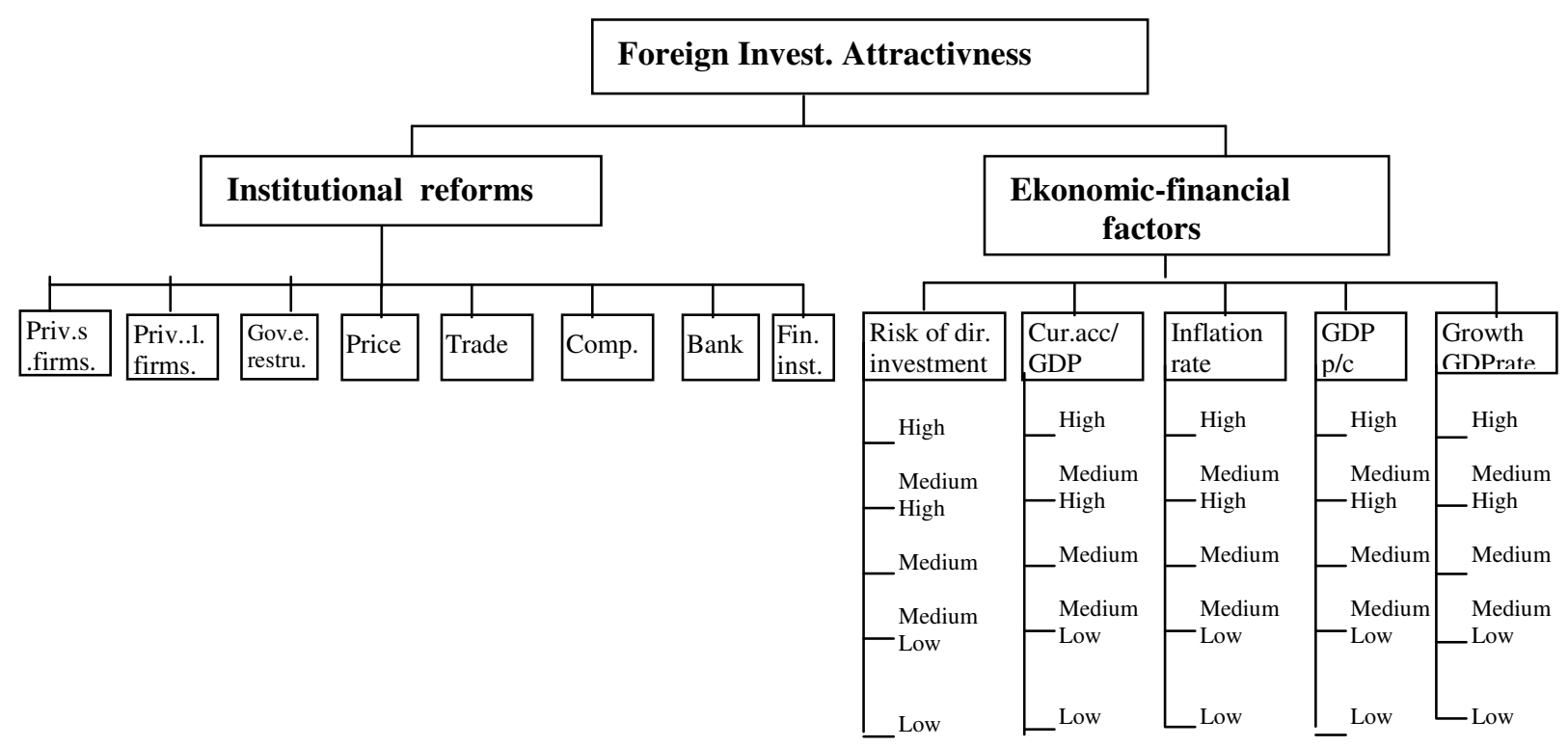


Nevertheless, we based the pairwise comparisons on the measured progress in structural reform of all transition economies as average indicator for each area of reform. The result is that the lowest progress has been realized by reform in competition policy, governance and enterprise reform and securities markets and nonbank financial institutions reform. The reached average progress can be indicator not only of complexity, but also an indicator of average progress in transition phase sequence. In both cases, it could be a good base for measuring and comparing the reached level of reforms in transitional countries. In such a way we avoid judgement inconsistency from the start.

The pairwise comparison matrix (Table 1) is based on average reached progress in structural reform ${ }^{3}$. The pairwise comparison values are:

1 = category $\mathrm{i}$ and $\mathrm{j}$ are of equal weights;

3 = category $i$ is of slightly more weight than category $j$;

$5=$ category $i$ is of more weight than category $j$;

7 = category $\mathrm{i}$ is of considerably more weight than category $\mathrm{j}$;

2, 4, 6 are intermediate values.

Table 1 Pairwise comparison matrix for institutional reforms

\begin{tabular}{|l||l|l|l|l|l|l|l|l||}
\hline & LP & SP & GR & PL & T & CP & BL & SFI \\
\hline \hline LP & 1 & 4 & $1 / 2$ & 2 & 3 & $1 / 4$ & $1 / 3$ & $1 / 4$ \\
\hline SP & & 1 & $1 / 5$ & $1 / 3$ & $1 / 2$ & $1 / 7$ & $1 / 6$ & $1 / 7$ \\
\hline GR & & & 1 & 3 & 4 & $1 / 3$ & $1 / 2$ & $1 / 3$ \\
\hline PL & & & & 1 & 2 & $1 / 5$ & $1 / 4$ & $1 / 5$ \\
\hline T & & & & & 1 & $1 / 6$ & $1 / 5$ & $1 / 6$ \\
\hline CP & & & & & & 1 & 2 & 1 \\
\hline BL & & & & & & & 1 & $1 / 2$ \\
\hline SFI & & & & & & & & 1 \\
\hline
\end{tabular}

Source: Lovrić, Lj. (2004), Measuring the Institutional Reform in Transition, in Readings Book of the International Conference - Global Business and Technology Association, Cape Town, June, ISBN:1-932917$00-4$, p.439-447.

The matrix (Table 1) is then used in third step of AHP procedure, that is calculation of vector of priorities for 8 reform categories. Computed vector of priorities is now the vector of weights. Each category of reform gets its own weight in the process of institutional reforms.

We shall use a sort of utility function - a mathematical representation of transition preferences, to determine the position of each country in the process of transition

\footnotetext{
${ }^{3}$ See Lovrić, Lj. (2004), Measuring the Institutional Reform in Transition, in Readings Book of the International Conference - Global Business and Technology Association, Cape Town, June, ISBN:1-93291700-4, p.439-447.
} 
according to the complexity and/or realised level of transition phase sequence of country reforms.

Utility function of transition is a weighted sum of transition indicators:

UTILITY $=\mathrm{w} 1 \mathrm{TI} 1+\mathrm{w} 2 \mathrm{TI} 2+\ldots \ldots \ldots \ldots .+\mathrm{wn}$ TIn

where are: $\quad$ TIi $=$ transition indicator of each country of the ith category,

wi $=$ weight of the ith category.

Table 2 Resulting Weighting from Pairwise Comparison for institutional reforms

\begin{tabular}{|l||l|}
\hline Category & Weight \\
\hline \hline LP & 0.078 \\
SP & 0.026 \\
GR & 0.116 \\
PL & 0.053 \\
T & 0.036 \\
CP & 0.260 \\
BL & 0.172 \\
SFI & 0.260 \\
\hline \multicolumn{2}{|l|}{ Consistency ratio $=0.042$} \\
\hline
\end{tabular}

Source: Lovrić,Lj. (2004), Measuring the Institutional Reform in Transition, in Readings Book of the International Conference - Global Business and Technology Association, Cape Town, June, ISBN:1-93291700-4, p.439-447.

$$
\begin{aligned}
\text { UTILITY }= & 0.078 \mathrm{LP}+0.026 \mathrm{SP}+.0 .116 \mathrm{GR}+0.053 \mathrm{PL}+0.036 \mathrm{~T}+0.260 \mathrm{CP}+ \\
& 0.172 \mathrm{BL}+0.260 \mathrm{SFI}
\end{aligned}
$$

Using utility function, weights and transition indicators in 2004 for eight transition categories, we obtain total values and also the percent of realized reforms in European transition countries (Table 6). There is also the maximum value, which is the advanced economies standard.

\subsection{The right side of AHP model}

The right side of the model (economic-financial factors) includes five factors' intensities: high, medium high, medium, medium low and low. The procedure continues with the specification of:

- relation between intensities and the rating grades of statistical data for each factor;

- pairwise comparison matrix components of the financial economic factors;

- pairwise comparison matrix for the rating grades for each of the five financial economic factors.

Relation between intensities and the rating grades of statistical data for each factor are defined in Table 3. Less preferred characteristics have lower rank, like significant inflation or investment risk. 
Table 3 Relation between intensities and the rating grades of statistical data

\begin{tabular}{||l||l|l|l|l|l||}
\hline \hline Sub criteria & High & Medium-High & Medium & Medium-Low & Low \\
\hline \hline Inflation(\%) & $<2$ & $2<<4$ & $4<<7$ & $7<<10$ & $10<$ \\
GDPgrowth(\%) & $>5$ & $5>>4$ & $4>>3$ & $3>>2$ & $2>$ \\
GDP pc (000\$) & $>9$ & $9>>7$ & $7>>5$ & $5>>3$ & $3>$ \\
Curr.acc/GDP $(\%)$ & $<-1$ & $-1<<-3$ & $-3<<-4$ & $-4<<-6$ & $-6<$ \\
Risk of dir.invest. & $>80$ & $80>>70$ & $70>>60$ & $60>>50$ & $50>$ \\
\hline
\end{tabular}

Source: Authors' estimation

Then the pairwise comparison matrix between the factors is made (Table 4). For example risk and growth are equally important and dominate in comparison to others. They are significantly more important than inflation and GDPp/c.

Table 4 Pairwise comparison matrix for economic-financial factors

\begin{tabular}{|l||l|l|l|l|l||}
\hline & $\begin{array}{l}\text { Risk of } \\
\text { dir.inv. }\end{array}$ & Curr.acc/GDP & Inflation & GDPpc & GDPgrowth \\
\hline \hline Risk of dir.inv. & 1 & 6 & 3 & 3 & 1 \\
\hline Curr.acc/GDP & & 1 & $1 / 2$ & $1 / 1$ & $1 / 6$ \\
\hline Inflation & & & 1 & 1 & $1 / 3$ \\
\hline GDPpc & & & & 1 & $1 / 3$ \\
\hline GDPgrowth & & & & & 1 \\
\hline
\end{tabular}

Source: Saaty \& Vargas (2001) Models, Methods, Concepts \& Applications of the AHP, Kluver Academic publishers, p.142-145

For each of the factor the intensity of priority is quantified and the pairwise comparison matrix is made. Then, the vector of priorities is evaluated for financial economic factors and their rating grades (Table 5).

Table 5 Priority vectors results - relative scores for factors and grades

\begin{tabular}{|l||l|l|l|l|l||}
\hline \hline & $\begin{array}{l}\text { Risk of } \\
\text { dir.inv. }\end{array}$ & $\begin{array}{l}\text { Cur.acc/ } \\
\text { GDP }\end{array}$ & $\begin{array}{l}\text { Inflation } \\
\text { rate }\end{array}$ & $\begin{array}{l}\text { GDP } \\
\text { p/c }\end{array}$ & $\begin{array}{l}\text { GDP Growth } \\
\text { rate }\end{array}$ \\
\hline \hline priorities & 0.353 & 0.058 & 0.118 & 0.118 & 0.353 \\
\hline Grades: & & & & & \\
H & 0.409 & 0.460 & 0.409 & 0.460 & 0.460 \\
MH & 0.295 & 0.299 & 0.324 & 0.299 & 0.299 \\
M & 0.117 & 0.144 & 0.159 & 0.144 & 0.144 \\
ML & 0.09 & 0.065 & 0.076 & 0.065 & 0.065 \\
L & 0.029 & 0.032 & 0.033 & 0.032 & 0.032 \\
\hline
\end{tabular}

Source: Saaty \& Vargas (2001) Models, Methods, Concepts \& Applications of the AHP, p.142-145

We continue by assigning rating intensity to each country in every financial economic category. The country ratings are evaluated by linear combination of priority weights 
of factors and grades assigned to the country. The results of evaluation are shown in Table 6 .

\section{THE ANALYSIS RESULTS}

A country rating in Table 6 is presented as percentage in two dimensions (criteria).

Table 6 Country ratings 1999 - 2004

\begin{tabular}{|c|c|c|c|c|c|c|c|}
\hline \multirow[b]{2}{*}{ Countries } & \multicolumn{6}{|c|}{ FINANCIAL ECONOMIC FACTORS } & INSTIT. \\
\hline & $\begin{array}{l}\text { Risk } \\
\text { of } \\
\text { dir.inv. }\end{array}$ & $\begin{array}{l}\text { Cur.acc/ } \\
\text { GDP }\end{array}$ & $\begin{array}{l}\text { Inflation } \\
\text { rate }\end{array}$ & $\mathrm{GDP} / \mathrm{pc}$ & $\begin{array}{l}\text { GDP } \\
\text { Growth } \\
\text { rate }\end{array}$ & \multirow[t]{2}{*}{$\begin{array}{r}\text { Rank } \\
(\%)\end{array}$} & \multirow[t]{2}{*}{$\begin{array}{r}\text { Rank } \\
(\%)\end{array}$} \\
\hline Priorities: & 0.353 & 0.058 & 0.118 & 0.118 & 0.353 & & \\
\hline CzechRep. & $\mathrm{MH}$ & ML & $\overline{\mathrm{MH}}$ & M & ML & 42.7 & 79.1 \\
\hline Estonia & MH & ML & M & ML & M & 42.4 & 76.7 \\
\hline Hungary & $\mathrm{MH}$ & M & ML & ML & $\mathrm{MH}$ & 53.9 & 83.7 \\
\hline Latvia & MH & $\mathrm{L}$ & $\mathrm{MH}$ & ML & $\mathrm{H}$ & 72.0 & 65.1 \\
\hline Lithuania & MH & $\mathrm{L}$ & $\mathrm{H}$ & ML & $\mathrm{L}$ & 39.7 & 72.1 \\
\hline Poland & $\mathrm{MH}$ & ML & ML & ML & M & 40.1 & 79.1 \\
\hline SlovakRep. & $\mathrm{MH}$ & ML & ML & ML & ML & 33.7 & 72.1 \\
\hline Slovenia & MH & MH & ML & $\mathrm{H}$ & MH & 66.5 & 69.8 \\
\hline Croatia & MH & ML & M & ML & ML & 36.0 & 65.1 \\
\hline Bulgaria & MH & ML & M & $\mathrm{L}$ & MH & 54.1 & 62.8 \\
\hline Romania & $\mathrm{M}$ & ML & $\mathrm{L}$ & $\mathrm{L}$ & $\mathrm{L}$ & 14.7 & 58.1 \\
\hline Refer.group & $\mathrm{H}$ & $\mathrm{H}$ & $\mathrm{MH}$ & $\mathrm{H}$ & $\mathrm{MH}$ & 84.6 & 90.7 \\
\hline Greece & MH & MH & MH & $\mathrm{H}$ & M & 60.8 & 90.7 \\
\hline Ireland & $\mathrm{H}$ & $\mathrm{H}$ & MH & $\mathrm{H}$ & $\mathrm{H}$ & 97.7 & 90.7 \\
\hline Portugal & MH & M & MH & $\mathrm{H}$ & M & 58.7 & 90.7 \\
\hline Spain & $\mathrm{H}$ & $\mathrm{H}$ & $\mathrm{MH}$ & $\mathrm{H}$ & M & 73.7 & 90.7 \\
\hline Eurozone & $\mathrm{H}$ & $\mathrm{H}$ & $\mathrm{H}$ & $\mathrm{H}$ & ML & 65.4 & 90.7 \\
\hline
\end{tabular}

Source: Authors' estimation

These are institutional reforms realization and financial economic factors levels attained. Transitional indicators are not statistically evaluated and published for the referent group, instead we have assigned them a value of 3.9 which is the average of EU countries. The highest position (100\%) corresponds to the value 4.3 of EBRD transition indicator and that means entirely realized institutional reforms or respectively high intensity of financial economic factors which determine a country attractiveness for investment. Based on the rating data of the countries, investment attractiveness map is developed in two dimensions - institutional reforms realization and financial economic factors levels (Figure 2). It represents the priority distribution of the countries for 1999-2004 time period. The CEE countries have better results in institutional reforms realization ( $71 \%$ in average) than in financial economic factors intensity (48\% in average). According to these average indicators, the map can be 
divided in four sub quadrants. The most attractive countries are in the highest sub quadrant and besides Ireland, Spain, Greece and Portugal, here are also transitional countries: Slovenia, Hungary and very close are the Czech Republic and Estonia.

Figure 2 AHP Results: Countries Positioning According to Institutional Reforms Realization and Financial Economic Factors Levels

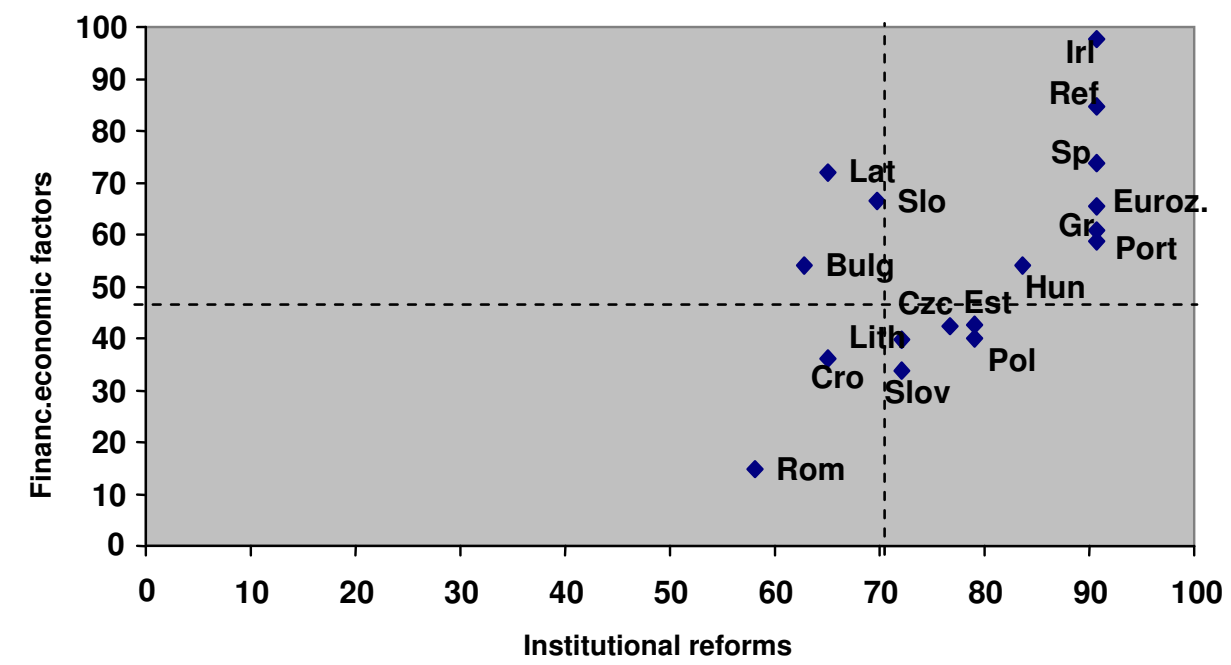

Source: Authors' estimation

\section{CONCLUSION}

Central European transitional countries attractiveness for foreign investment is evaluated in the paper. It is realised through two dimensions of transitional progress achieved level, measured by economic performances factors and institutional reforms indicators. This is a complex hierarchically structured decision-making task which includes qualitative and quantitative indicators. The reached level of country's institutional reform progress is precisely measured as a weighted sum of EBRD transition indicators according to the reform category complexity.

The CEE countries in average have better results in institutional reforms realization (71\%) than in financial economic factors intensity $(48 \%)$. The most attractive for investments are in sequence: Slovenia, Hungary, the Czech Republic, Estonia and Poland.

\section{REFERENCES}

EBRD, (2003,2005), Transition Report.

Eurostat, (2005), ECB Eurocomission.

http://stats.unctad.org/fdi/ 
Lovrić,Lj.(2004), Measuring the Institutional Reform in Transition, in Readings Book of the International Conference - Global Business and Technology Association, Cape Town, June, ISBN:1-932917-00-4, p.439447.

Saaty,T.A.(1986), Axiomatic Foundation of the Analytic Hierarchy Process, Management Science, Vol.32, No 7 ,

Saaty, T.L. and Vargas, L.G.(2001), Models, Methods, Concepts \& Applications of the Analytic Hierarchy Process, Kluwer Academic Publishers. 
Ljiljana Lovrić, Ph.D.,

++385 51355154

llovric@efri.hr

University of Rijeka, School of Economics Rijeka,

51000 Rijeka, I.Filipovića 4, Croatia

Vinko Kandžija, Ph.D.,

++385 51355130

kandzija@efri.hr

University of Rijeka, School of Economics Rijeka,

51000 Rijeka, I.Filipovića 4, Croatia

Jelena Babić, M.sc.,

Ph.D.,

++385 51355162

jelena_babic@efri.hr

University of Rijeka, School of Economics Rijeka,

51000 Rijeka, I.Filipovića 4, Croatia

ATTRACTIVENESS OF CENTRAL EUROPEAN TRANSITIONAL COUNTRIES FOR FOREIGN INVESTMENT

Ljiljana Lovrić

University of Rijeka, School of Economics, Rijeka, Croatia 
Vinko Kandžija

University of Rijeka, School of Economics, Rijeka, Croatia

Jelena Babić

University of Rijeka, School of Economics, Rijeka, Croatia

ATTRACTIVENESS OF CENTRAL EUROPEAN TRANSITIONAL COUNTRIES FOR FOREIGN INVESTMENT

Key words: transition, analytic hierarchy process, investments

\section{ABSTRACT}

In this article Central European Countries are ranked depending on how attractive they are to international companies for investment. In the process of managerial decisionmaking about investment, companies mostly use statistical data published by international institutions. Such wide and heterogeneous set of quantitative and qualitative information need to be compared and analyzed systematically, and it can be done by using the method of Analytical Hierarchy Process (AHP). An estimation is performed considering two important aspects simultaneously - the level of institutional reforms being realized and the level of economic performances attained by an individual country.

\section{CONCLUSION}

Central European transitional countries attractiveness for foreign investment is evaluated in the paper. It is realised through two dimensions of transitional progress achieved level, measured by economic performances factors and institutional reforms indicators. This is a complex hierarchically structured decision-making task which includes qualitative and quantitative indicators. The reached level of country's institutional reform progress is precisely measured as a weighted sum of EBRD transition indicators according to the reform category complexity.

The CEE countries in average have better results in institutional reforms realization (71\%) than in financial economic factors intensity (48\%). The most attractive for investments are in sequence: Slovenia, Hungary, the Czech Republic, Estonia and Poland. 